\title{
LXIII. Complete collection of Kepler's works
}

\section{Dr. J. Lhotsky}

To cite this article: Dr. J. Lhotsky (1846) LXIII. Complete collection of Kepler's works, Philosophical Magazine Series 3, 28:188, 387-393, DOI: 10.1080/14786444608645440

To link to this article: http://dx.doi.org/10.1080/14786444608645440

$$
\text { 册 Published online: } 30 \text { Apr } 2009 .
$$

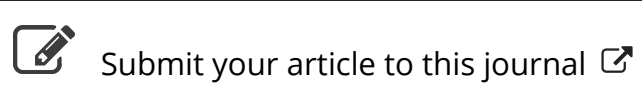

\footnotetext{
Џ Article views: 4
}

Q View related articles $\sqsubset$ 
pose be not forestalled by other publications. This he did not do; and to the edition of 1614 the editor appended the tables which Ralph Handson had published in his translation of the Trigonometry of Pitiscus (of the first edition of which I have not found the date). The first sines actually published, as far as I can find, were those at the end of 'Thomas Fale's Horologiographia, first published in 1593; they are to minutes, with a radius of 100000 . The first complete canon which I can find is that of Blundeville, in his Exercises, first published in 1597. They are taken from Clavius, and are to every minute, with a radius of ten millions. These Exercises went through seven editions at least, and were latterly corrected from Pitiscus. John Speidell, well-known afterwards for his logarithms, published a small table in 1609 , to every ten minutes, and to a radius of 1000 . Briggs began his calculation of sines about 1600, in ignorance, we may suppose, of the appearance of the Opus Palatinum four years before. This is all I have been able to find on the matter.

There is a work expressly on the history of the trigonometrical canon, which is sometimes cited by foreign writers; it is by Frobesius, and was printed at Helmstadt about 1750; but I cannot find any copy of this work in London.

LXIII. Complete Collection of Kepler's Works. By Dr. J. Lhotsky,*

PROFESSOR Frisch of Stutgardt has recently published a programme of his intended collection of the works of the great German astronomer and philosopher, which, like a splendid luminary, will enliven the dim polygraphy of the present age. Considering Kepler as the real founder of modern astronomy, the collecting of his works (many of them very rare) is a tribute most due to such great merit. Our present epoch seems especially adapted to such an undertaking. Monuments are everywhere raised to the honour and memory of men who have deserved well of humanity or of their country, in one or another department of human knowledge or enterprise. In following up the track marked out by Kepler in astronomical science, a degree of accuracy and perspicuity has been acquired, which is one of the proudest trophies of the human mind. In such a time, it is impossible that the claims and memory of Kepler could be kept in abeyance any longer. $\mathrm{He}$, the modest searcher and deep thinker, ought to obtain his share of attention and general recognition, so long with-

* Communicated by the Author. 
held from him,-whose discoveries have been confirmed in so splendid a way.

Something, it is true, has been done in the way of atonement towards his long-neglected memory; and it is now thirty-seven years since over his grave at Regensburg (his native city), the image of the great man was placed under the cupola of a monument, on the anniversary of his birth-day, amid the roar of cannon. It cannot, however, be said that this slight token of gratitude could suffice to the memory of one whom his coevals left in misery and distress, while occupied with the examination of the very innermost secrets of science; while at the same time the produce of a painful and thorny life, his splendid works, remained unknown and forgotten. It is true, his name is on the lips of every astronomer and philosopher; the three great Keplerean laws are yet the main basis of the knowledge of the heavens; still his works moulder in dust and oblivion. On the other hand, it must be acknowledged that the present position of mathematical science is far different from what it was in the seventeenth century; and problems are now solved with facility and speed which then occasioned much labour; and many a deep axiom and saying of Kepler will be more easily appreciated if presented to the reader in a more modern garb. But it is not merely the contents, but even the form and style of the immortal astronomer's works, which imparts value to them; and it requires but little attention to become familiar with that form, albeit hidden and enigmatic.

There are two reasons, however, which have hitherto prevented the greater spread of Kepler's works,-their rarity and their external appearance. There is hardly a library in Europe where all the works of Kepler are to be met with, and many where even the most important are wanting. The cause is obvious. In the then condition of typography and publishing, only a few copies could be printed, and of those many were lost in conveying them about the country and by other accidents. Thus, for instance, Kepler's Harmonie and Astronomia Nova are so scarce, that only the largest libraries can boast of their possession. The next cause of the neglect of our author's works, is the wretched type, bad paper, and the improper size of many of them. The figures, moreover, are so badly designed, and the letters thereon so indistinct, that they cannot be read without difficulty. 'These reasons will be deemed sufficient for making a collection of Kepler's works. It was the late Prof. Pfaff at Eslingen, who, in 1810, first conceived this design, which, however, did not come to maturity. Still, constant communications with this gentleman 
kept the conviction of the importance of such an undertaking alive, and a further investigation of the great work increased the interest for the old astronomer and philosopher. The present editor, however, Prof. Frisch, did not long enjoy the assistance of either Pfaff, or of the great philologist, Prof. Kopp, both being carried off by premature death. The labour was subsequently much aided by the head librarians of Stutgardt and 'Tubingen, who defrayed the preparatory expenses of the undertaking. Of especial use also was the library of Reütlingen, which contains a very complete collection of the mathematical works of the sixteenth century. All this must of necessity have led to the inquiry after the original MSS. of Kepler, a notice of which is to be found in Murr's Journal für Kunstgeschichte und allgemeine Literatur, vols. iii. and xvii. It is to the following effect:--Kepler's son Ludwig, who died in 1663, had preserved the MSS. of his father with the intention of publishing a selection from them. In fact, there appeared in 1634, through his endeavours, a work which, however, the father had prepared for the press, viz. Somnium sive de Astronomiá lunari. All the rest remained unused, most probably because Iudwig, who was a physician, could not understand the problem of his great progenitor. From him the MSS, went to the celebrated Selenographer Hevel, and thence to his son-in-law, the common-councilman Lange at Dantzig. Of Lange they were bought in 1707 by the Leipzig mathematician, Hansch, for 100 florins. They consisted of twentytwo folio volumes, which, besides the drafts of several works already printed (for instance, the Harmonie, the Rudolphine Tables, \&c.), contained the correspondence of Kepler with many distinguished personages, several astronomical works merely begun, and a host of miscellaneous notices. Hansch intended to publish these MSS. in a splendid form, but was only able to begin this undertaking (too costly in the form he had projected it), and the Epistole ad Keplerum scripta, insertis ad easdem responsionibus Keplerianis, which was patronized by the emperor Charles VI., was the only result he ever achieved. The MSS. thus published, are to be found in the Imperial Library of Vienna. As Hansch fell into poverty, he was obliged to pledge the MSS.; and as he could not redeem them, one Etringer, of Frankfort on the Maine, redeemed them for 128 florins. 'Thence they came (probably by inheritance) to a Mrs. Trümmer at Frankfort, where they remained unknown until 1770, when Christopher de Murr, a man deserving well of literature, called attention to them. For the purpose of recovering them from oblivion, he addressed himself to several astronomers, as Mayer, Bernouilli, 
Kästner, \&c.; but besides laudatory commendations on his undertaking, they could not afford any substantial aid. Consequently Murr sent the catalogue of the MSS. to St. Petersburg, and solicited Euler for his intercession. On the recommendation of the latter and other savants, they were purchased in 1774 for the St. Petersburg Imperial Academy. The academicians Euler, Kraff, and Lexell received orders to peruse the MSS, and to select those worthy of publication. Lexell began the revision of a nearly completed work of Kepler's, on the motion of the moon, entitled Hipparchus; but there it ended, and neither the work nor the promised completion ever saw the light. These MSS. have ever since reposed, as Prof. Krafft writes, "an ornament of the Petersburg Library," - useless, unknown. Prof. Frisch took great pains to obtain these MSS. Introduced by Baron de Regendorff, Russian Minister at Stutgardt, and Prof. Schelling, he addressed himself to the imperial government, and received the assurance that the use of them would be granted to him; and from the known scientific munificence of the Petersburg cabinet, it is to be hoped that his further request for the loan of the MSS. will be shortly granted.

As to the plan on which the works are to be edited, Prof. Frisch makes the following statement:-The original text will remain unchanged, except where palpable error has crept in, as it is intended that Kepler shall appear throughout in his truest form. The notes will be as few and concise as possible, in order not to increase the bulk of the work; they will treat either on historical points, or explain difficult passages. As most of the works of Kepler are in Latin, the adoption of that language for the notes has been deemed expedient. The introduction which will precede the whole is to contain a survey of the condition of mathematical and natural science in the century preceding the life of Kepler, and to this will be attached his biography, mostly relating to his scientific labours. But as it is possible that some of the MSS. at St. Petersburg may contain materials for the elucidation of this subject, the compiling of it will be deferred until it shall be ascertained whether permission will be granted for the use of them.

The works will, as far as possible, be printed in the order in which Kepler composed and published them. But those relating to chronology will be put together, and those consisting mostly of numerals, as the Ephemerides, the Rudolphine Tables, and the work on Logarithms, will form the last part of the collection. Prof. Frisch concludes his programme by calling upon all friends of science to aid him in an under- 
taking the difficulty of which he is perfectly aware of. Every communication made to him will be received with thanks. The owner's of MSS. of Kepler especially might greatly assist the undertaking by the loan of them, or the transmission of accurate copies. Even of the printed works of Kepler, Prof. Frisch has not been able to see the following:-

1. Almanack of the Year 1594*.

2. De Fundamentis Astrologia, Prague 1602.

3. Epistola ad rerum coelestium amatores de Salis deliquio, Prague 1605.

4. Dissertatio cum nuncio sidereo, \&c., Florence 1610, 4to. [The edition of Prague 1610, 4to, and Frankfort 1611, 8vo, are at hand.]

5. Responsio ad Epislolam Bontschii, Sagan 1609.

In conclusion, Prof. Frisch requests the loan, or offers the purchae of any of these works of Kepler.

A considerable time having elapsed since the programme of the Stutgardt Professor was published, the aim of which undoubtedly was to excite attention in, and to obtain aid also from, this country, which has associated itself in every useful undertaking all over the world, I have now been induced to take up this subject, as my studies at Prague had led me often in the very track of the life of Kepler, who remained eleven years in that city. But the attention of an English public cannot and ought not to be called for without searching for some connecting link between the activity of Kepler and those of English savants. A brief search, indeed, showed me that such existed, and I have been able to complete and correct the programme of Prof. Frisch. If we refer to the names of the various possessors of Kepler's MSS., we find that it was Hevel who obtained them from Kepler's son, and we find the number of volumes or fasciculi to have been twenty-two. It was not to be supposed that the Stutgardt Professor should have known the long array of volumes composing the Philosophical Transactions of the Royal Society, else he would have found a letter of that very Hevel addressed to the Society (or their publisher) on these very MSS., in which they are called the famous Kepler MSS. (vide Phil. Trans, vol. ix. No. 102, p. 27, anno 1674). The title of this remarkable communication is as follows:- "An Extract of M. Hevelins's Letter, lately written to the publisher, concerning the famous Kepler's MSS., together with some Observations of his about the

* This is the first thing Kepler printed at Gratz. It is very probable that a copy of this work may exist safe in some neglected collection of rubbish. 
Use of Telescopic Sights in Astronomical Observations." In looking over this letter, we find that the number of fasciculi in Hevel's possession was not twenty-two, as stated (or at least implied) by Prof. Frisch, but twenty-nine fasciculi. One thing, moreover, is certain, that Hevel must have possessed all the MSS.; deriving them from a source where certainly they had received the highest possible attention. In perusing, therefore, the catalogue of these MSS., as given by Hevel in his letter to the Royal Society, we shall find that Prof. Frisch's hopes or expectations as to what the St. Petersburg documents may contain, can be at once answered, because Hevel could never have had less than what is at St. Petersburg now; though he might have had more, which, however, would make the case worse. A very short time, in fine, will now set the matter at rest. In regard to Kepler's life, Hevel says as follows:- "At Kepleri vitam studio conscriptam non invenio; interim plurima notatu dignissima, vitam ejus spectantia passim notavi, ex quibus vita ejus possit haud obscurè depingi. Quæ verò in specie ex scriptis ejus penes me habeo, catalogus hicce indicabit" (Ibid.). Whatever fates these MSS. might have subsequently undergone, Hevel's Catalogue must ever be considered the most complete. The extract from Hevel's letters to the Royal Society (as printed in the Phil. Trans.) does not imply any especial offer or request. But there exists among the MSS. of the British Museum, another document relating to these MSS., and this is an autograph letter of Hansch to the Royal Society; it is dated Vienna, November 20, 1734. There Hansch speaks of twenty-two fasciculi, and as this was written after his Epistole ad Keplerum were published, it may be presumed that seven might have merged (whether entirely or partially is not known) in this undertaking. Hansch's letter contains also a list of the Kepler fasciculi, but they seem to have been re-arranged, as the contents of most, as given by Hevel and Hansch, do not correspond. It is, moreover, curious that Prof. Frisch says that the Epistola ad Keplerum were all that Hansch published, while the letter in the British Museum says, "Præter Epistolas, quæ in folio charta augusta prodierunt, et Librum singularem de Calendario Gregorio quem Ratisbone 1726-in folio pariter typis imprimendum curavi-reliqua MSS. REGIAM desiderant munificentiam." Hansch's letter is entirely lachrymose and supplicatory; and it is a pity to perceive that these MSS. had something ominous in them, as not only their author, but even several of their subsequent owners fell into deep distress.

Having been so far successful in my research, I resolved to 
see whether some of the works of Kepler, which Prof, Frisch could not discover in Germany, might not be found in our libraries, which certainly are surpassed by the richness of especial departments of those of the respective countries; and none would expect, for instance, to find more Austrian Incunabula in English libraries than there are in Vienna, \&c, But taking the biographical opulence at a fair average, the balance will not be unfavourable for this small and insulated empire. The very first glance I cast in the Catalogue of the British Museum (even in its present transitory state) was encouraging, as I found No. 5 of Prof. Frisch's Desiderata. The full title of this little rarity is as follows:- Joannis Kepleri Mathematici ad Epistolam Clarissimi Viri D. Jacobi Bartschii Laubani Medicince Candidati Prafixam Ephemeridi in anno 1629 Responsio : de Computatione et Editione Ephemeridum, Typis Saginensibus 1629." It is a small 4to pamphlet of only eleven pages, printed on paper and with a type of the then current publications of the day. The conclusion is so characteristic of the man, that we shall translate it:- "6 But while the storm is raging, and the shipwreck threatens public affairs, nothing remains to us but to let the anchor of our innocuous studies go down to the profound of eternity! Given at Sagan in Silesia, with our own types, anno 1628." It is known that Kepler had been in some relation with the great Wallenstein, and the place of printing is one of the possessions of the great warrior, he having been Duke of Sagan, The name of the duke is also mentioned in the contents of the work.

London, April 15, 1846.

LXIV. On the Aberration of Light, in Reply to Mr. Stokes. By the Rev. J. Challis, M.A., Plumian Professor of Astronomy in the University of Cambridge.

To the Editors of the Philosophical Magazine and Journal. Gentlemen,

I HAD reason to expect, when I made my last communica1 tion on the Aberration of Light, that I slıould not have occasion to trouble you again on this subject. Mr. Stokes's remarks in the April Number compel me to say a few words more.

I can assure $\mathrm{Mr}$. Stokes that I take the aberration of light in its usual acceptation, and I have no doubt that he does also. The difference between us is not in the thing explained, but in the principles of our explanations. My explanation, which is very simple and brief, being entirely contained in

Phil. Mag. S. 3. Vol. 28. No. 188. May 1846. 2 E 